\title{
PROFIL PEMBELAJARAN BERBASIS DARING DALAM PELAJARAN BAHASA JEPANG PADA SISWA KELAS XI BAHASA DI SMA N 2 BANJAR
}

\author{
N.M.S. Utami ${ }^{1}$, G.S. Hermawan ${ }^{2}$, I.W. Sadyana ${ }^{3}$ \\ ${ }^{123}$ Jurusan Pendidikan Bahasa Jepang, Universitas Pendidikan Ganesha, Singaraja \\ e-mail: sidautami5@gmail.com, satya.hermawan@undiksha.ac.id, wayan.sadyana@undiksha.ac.id
}

\begin{abstract}
Abstrak
Penelitian ini bertujuan untuk mengetahui (1) Pemaparan pembelajaran secara daring dalam pelajaran bahasa Jepang pada siswa kelas XI bahasa di SMA N 2 Banjar, (2) Mengetahui kendala yang ditemukan selama pembelajaran berbasis daring. Pengumpulan data dilakukan dengan metode observasi, wawancara, dan dokumentasi kemudian dianalisis dengan metode deskriptif kualitatif. Hasil penelitian menunjukkan bahwa (1) Guru melakukan pembelajaran berbasis daring dengan baik, dilihat dari kesiapan sebelum mengajar guru mempersiapkan segala sesuatu untuk memperlancar pembelajaran, (2) Kendala yang dihadapi guru dalam mengajar bahasa Jepang berbasis daring yaitu: sinyal internet tidak stabil, kehadiran siswa tidak $100 \%$, kuota internet terbatas, pembelajaran daring kurang efektif, siswa tidak mempunyai ponsel, dan tugas rumah semakin banyak.
\end{abstract}

Kata kunci: Profil, Berbasis daring, Kendala.

\author{
要旨 \\ 本研究の目的は 1） バンジャル第二国立高校の言語学科の三年生におけるオンラ \\ インに基づく日本語の授業、2）オンラインに基づく授業中に直面する障害 を明らかにすること。 \\ データ収集は観察、面接、文献調査 を使用し定性的記述法によって分析した。結果は 1 ）教師は \\ オンラインの授業を非常にうまくできた。それは 先生の教える前の準備から知られている、2）障 \\ 害は インターネット信号が不安定、学生の出席率が 100\%でない、インターネットの割り当てが制 \\ 限されている、授業が効果的でない、学生が携帯電話を持っていない、宿題が増えていることである。 \\ キーワード： 概要、オンライン、障害
}

\section{Pendahuluan}

Dengan tatanan kehidupan yang baru (new normal) masyarakat mulai melakukan aktivitas secara normal tentunya dengan menaati PROKES yang ketat. Menjaga jarak, menggunakan masker, dan mencuci tangan dengan menggunakan sabun. Penyebaran virus COVID-19 melalui transmisi lokal memang sangat melonjak pada saat ini. Sehingga KEMENDIKBUD mengeluarkan surat edaran tentang pembelajaran yang dilakukan di sekolah dialihkan dengan belajar di rumah saja untuk memutus rantai penyebaran virus COVID-19.

Belajar berbasis daring dapat diartikan sebagai kegiatan yang berbasis teknologi yang dapat diakses melalui jarak jauh secara online dengan menggunakan berbagai plattform yaitu Google Classroom dan Edmodo. Selain itu banyak guru yang menggunakan plattform Zoom Metting dan Whattsap Group untuk melancarkan proses pembelajaran berbasis daring (Nadia, 2020). 
Pembelajaran daring sudah diterapkan di berbagai lembaga pendidikan untuk memperlancar kegiatan belajar mengajar. Mulai TK sampai jenjang perguruan tinggi sudah menerapkan pembelajaran berbasis daring. Termasuk di SMA N 2 Banjar yang sudah menerapkan pembelajaran berbasis daring. SMA N 2 Banjar merupakan sekolah yang paling banyak diminati oleh siswa dibandingkan dengan sekolah yang berada di wilayah Banjar, dan merupakan sekolah yang paling banyak jumlah siswanya.

Di SMA N 2 Banjar mata pelajaran bahasa Jepang bagi jurusan bahasa yakni dikategorikan sebagai mata pelajaran wajib. Kemudian untuk jurusan IPA dan IPS mata pelajaran bahasa Jepang merupakan ilmu lintas minat sesuai dengan kurikulum 2013.

Dalam pembelajaran bahasa Jepang, aspek kebahasaan yang memiliki peran yang sangat penting yaitu kosakata, pengucapan, ejaan huruf, tata bahasa, dan ejaan komunikatif. Kosa kata dianggap penting yang harus dikuasi dalam belajar bahasa Jepang karena keterampilan suatu bahasa dapat dilihat dari seberapa besar penguasaan kosakata tersebut (Hardjono, 1988:17).

Sudjianto dan Dahidi (2012:97), mengatakan bahwa kosakata (gol) merupakan aspek kebahasaan yang harus diperhatikan dan dipahami untuk memperlancar komunikasi dengan baik secara tulisan maupun lisan. Kemudian Asano (1981:3) mengungkapkan bahwa tujuan akhir pengajaran bahasa Jepang adalah agar siswa mampu mengkomunikasikan pikiran mereka dengan menggunakan bahasa Jepang baik secara lisan maupun tulisan dengan menguasai kosakata.

Pada wawancara yang sudah dilakukan dengan guru SMA N 2 Banjar diketahui bahwa pembelajaran bahasa Jepang berbasis daring masih kurang efektif dibandingkan dengan pembelajaran luring. Guru susah merangkum KBM dalam pembelajaran daring dikarenakan guru tidak tahu betul apakah siswa benar-benar memahami materi pelajaran atau tidak. Belajar daring bisa dilakukan dimana saja dan kapan saja tanpa batas. Pembelajaran berbasis daring sudah berdasarkan dengan kurikulum 2013. Strategi yang digunakan yaitu startegi tanya jawab dan ceramah. Pada saat pembelajaran berbasis daring berlangsung siswa terlihat bosan ataupun tidak fokus dan susah mengingat materi pelajaran. Kemudian ketika guru bertanya siswa tidak bisa menjawab pertanyaan.

Saat ini belum ada penelitian sejenis mengenai profil pembelajaran berbasis daring dalam pelajaran bahasa Jepang pada siswa kelas XI bahasa di SMA N 2 Banjar. Ditemukan beberapa penelitian yang sejenis mengenai pembelajaran berbasis yang dilakukan oleh Kuartanto E (2017).

Dalam penelitian sebelumnya yang dilakukan oleh Kuartanto $E(2017)$ yaitu meneliti tentang mata pelajaran bahasa Indonesia pada tingkat perguruan tinggi dengan menggunakan model pembelajaran daring. Persamaannya yaitu sama-sama meneliti tentang pembelajaran berbasis daring. Perbedaan penelitian yang dilakukan oleh Kuartanto E (2017) dengan penelitian ini yaitu pada penelitian Kuartanto E (2017) menggunakan pendekatan konstruktif dengan jenis penelitian kuasi eksperimen, sedangkan penelitian yang dilakukan oleh penulis menggunakan metode deskriptif kualitatif. Subjek yang berbeda yaitu pada penelitian Kuartanto E (2017) meneliti di perguruan tinggi sedangkan penelitian ini di sekolah menengah atas (SMA).

\section{Kajian Pustaka}

Pada penelitian ini dapat dibedakan teori utama dan teori pendukung. Teori utama yang digunakan adalah teori belajar dan pembelajaran (Dimyati dan Mudjino,2013), teori pembelajaran bahasa Jepang Dasar, teori strategi pembelajaran, teori jenis-jenis strategi pembelajaran, teori kosa kata Bahasa Jepang (Sudjianto dan Dahidi, 2012).

\section{Belajar dan Pembelajaran}

Belajar merupakan kegiatan untuk mengetahui pengetahuan, meningkatkan kemampuan, membenahi sikap, dan menguatkan diri sendiri. Menurut pemahaman sains konvensiona pada proses meningkatkan kemampuan pengetahuan hubungan antara manusia dengan alam dinamakan dengan pengalaman (experience). Pengalaman yang 
sudah terjadi secara berulang akan memunculkan pengetahun (knowledge) (suyono dan Hariyanto, 2019:9).

Skinner mengatakan bahwa belajar merupakan suatu tingkah laku atau prilaku. Ketika orang mulai belajar maka akan mendapatkan komentar yang baik. Abegitu pula sebaliknya bila tidak belajar maka komentar yang baik akan menurun. Ketika belajar akan ditemukan hal sebagai berikut : (1) kesempatan terjadinya peristiwa, (2) Respon pembelajar, (3) konsekuensi yang bersifat menguatkan respon (Dimyati dan Mudjinono, 2013:9).

\section{Pembelajaran Bahasa Jepang Dasar}

Pada kegiatan belajar, pengajar diharuskan untuk mengajarkan siswa tentang pembelajaran bahasa Jepang dasar. Pembelajaran bahasa Jepang dasar yaitu kegiatan belajar yang membahas tentang pelajaran yang menjelaskan tentang hal dasar kepada siswa misalnya huruf, lafal, kosa kata, yang sesuai dengan konteksnya.

Pada buku Shokyu o oshieru (初級を教える) (2007:13) menyebutkan bahwa ada 3 tahapan yaitu 分かる (pemahaman), 覚える (mengingat), 使える (penggunaan).

\section{Strategi Pembelajaran}

Menurut J.R David, 1976 (dalam sanjaya ,2006) strategi pembelajaran merupakan a plan, method, or series of activities designed to achieves a particular educational goal. Dapat diartikan strategi pembelajaran adalah aktivitas yang dilakakukan untuk meraih tujuan pendidikan yang ingin dicapai.

\section{Metode}

Penelitian ini dilaksanakan di SMAN 2 Banjar pada siswa kelas XI tahun ajaran 2020/2021. SMA N 2 Banjar merupakan sekolah menengah atas negeri yang berlokasi di Jalan Banteng, Banjar Tegeha, Kecamatan Banjar, Kabupaten Buleleng Provinsi Bali.Waktu penelitian dilaksanakan dari kegiatan awal hingga penyusunan laporan penelitian.

Pendekatan yang digunakan dalam penelitian ini adalah pendekatan deskriptif kualitatif. Dalam penelitian ini akan dideskripsikan tentang pembelajaran berbasis daring dalam pelajaran bahasa Jepang pada siswa kelas XI di SMA N 2 Banjar, dan kendala yang dihadapi selama pembelajaran berbasis daring dilaksanakan. Sumber data utama dalam penelitian ini adalah hasil wawancara dan hasil observasi yang dilakukan pada guru mata pelajaran bahasa Jepang di SMA N 2 Banjar. Observasi dilakukan selama pembelajaran bahasa Jepang di kelas XI bahasa berlangsung melalui aplikasi google classroom dan zoom.

Metode pengumpulan data dalam penelitian ini dilakukan dengan 3 cara yaitu observasi, dokumentasi, dan wawancara.

Observasi dilakukan selama pembelajaran bahasa Jepang di kelas XI Bahasa berlangsung melalui aplikasi google classroom. Dan zoom metting. Dalam pelaksanaannya, metode observasi dibantu dengan teknik catat yaitu mencatat kejadian-kejadian yang terjadi di dalam kelas selama proses pembelajaran daring berlangsung.

Observasi dilakukan sebanyak 5 kali. Observasi pertama dilakukan tanggal 12 Oktober 2020, kedua dilakukan tanggal 4 November 2020, observasi ketiga dilakukan tanggal 9 November 2020, observasi keempat dilakukan tanggal 18 November 2020, kemudian observasi kelima dilakukan pada tanggal 2 Desember 2020.

Wawancara dilakukan pada 23-25 September 2020 pada guru untuk menanyakan hal-hal terkait persiapan, bahan ajar, metode dan penilaian pembelajaran Bahasa Jepang. Pengumpulan data melalui wawancara dilakukan dengan menggunakan pedoman wawancara dan alat perekam suara digital. Data yang dikumpulkan dianalisis dan dideskripsikan secara kualitatif.

Analisis data pada penelitian ini sesuai dengan tujuan penelitian, yaitu mendeskripsikan pembelajaran berbasis daring dalam pelajaran bahasa Jepang pada siswa kelas XI bahasa di SMA N 2 Banjar dan kendala yang dihadapi selama melakukan pembelajaran berbasis daring. Dalam penelitian ini, data-data yang diperoleh dianalisis menggunakan metode analisis deskriptif kualitatif, yakni mendeskripsikan data melalui uraian 
dan penjelasan. Prosedur yang ditempuh dalam menganalisis data pada penelitian ini yakni (1) reduksi data, (2) penyajian data, (3) penarikan kesimpulan.

\section{Hasil dan Pembahasan}

Observasi pertama dilakukan di kelas XI bahasa . Pada tanggal 12 Oktober 2020. Tema pembelajaran pada waktu itu adalah "Lingkungan Rumah" (Uchi). Observasi kedua dilakukan pada tanggal 4 November 2020. Tema pembelajaran pada waktu itu masih sama yaitu tentang "Lingkungan Rumah" (Uchi). Observasi ketiga dilakukan pada tanggal 9 November 2020. Tema pembelajaran pada waktu itu adalah "Hobi" (shumi). Observasi keempat dilakukan pada tanggal 18 November 2020 dengan tema yang masih sama yaitu tentang "Hobi dan kesukaan". Observasi kelima dilakukan pada tanggal 2 Desember dengan melakukan kegiatan pengulangan materi yang sudah pernah diajarkan sebelumnya.

Kemudian data hasil wawancara memuat tentang hasil wawancara yang dilakukan dengan narasumber yaitu guru pengampu mata pelajaran bahasa Jepang kelas XI bahasa di SMA N 2 Banjar. Wawancara ini dilakukan pada hari senin 12 Oktober 2020. Proses wawancara dilakukan secara online melalui panggilan vidio whattshap. Wawancara ini dilakukan diluar jam pembelajaran daring. Dalam melakukan wawancara, peneliti menggunakan pedoman wawancara yang berkaitan dengan pembelajaran bahasa Jepang.

\section{Pembahasan}

Pembelajaran berbasis daring yang dilaksanakan dalam pelajaran bahasa Jepang pada siswa kelas XI Bahasa di SMA N 2 Banjar dilakukan dengan sangat baik. Hal tersebut dapat dilihat dari kesiapan guru sebelum mulai mengajar secara daring.

Guru menggunakan buku pedoman Nihon Go Kira-Kira kelas XI kemudian menggunakan materi digital dari buku Nihon Go Kira-Kira berbentuk PDF yang di download dari web Erlangga. Dalam pembelajaran daring guru menggunakan media power point dan vidio yang menarik untuk menjelaskan materi pelajaran. Kemudian plattform yang digunakan guru yaitu Google Classroom, Zoom Metting, dan Whattsap group untuk mempermudah pembelajaran secara daring. Pembelajaran berbasis daring dilakukan sesuai dengan kurikulum 2013 yang berlaku.

Kendala yang dipaparkan pada penelitian ini yaitu kendala-kendala yang dihadapi guru selama pelaksanaan pembelajaran berbasis daring dalam pelajaran bahasa Jepang pada siswa kelas XI bahasa di SMA N 2 Banjar. Hasil penelitian menunjukkan bahwa terdapat beberapa kendala yang dihadapi guru dalam melaksanakan pembelajaran secara daring yaitu sinyal yang tidak stabil, kuota internet yang terbatas sehingga siswa agak kesulitan untuk mengikuti pembelajaran secara daring, siswa tidak mempunyai ponsel untuk mengikuti pembelajaran daring, kegiatan pembelajaran menjadi kurang efektif selama pembelajaran daring, dan tugas rumah yang semakin banyak sehingga siswa mengeluh dengan hal tersebut.

\section{Simpulan dan Saran}

Berdasarkan hasil analisis dan pembahasan tentang pembelajaran berbasis daring dalam pelajaran bahasa Jepang pada siswa keklas XI bahasa di SMA N 2 Banjar yaitu:

Pertama, Pembelajaran berbasis daring yang sudah dilakukan oleh guru sudah berjalan dengan baik. Hal tersebut dapat dilihat dari kesiapan guru sebelum memulai kegiatan pembelajaran secara daring. Buku yang digunakan yaitu Nihon Go Kira-Kira kelas $\mathrm{XI}$ dengan menggunakan media pembelajaran power point dan vidio yang menarik. Kemudian plattform yang digunakan yaitu Google Classroom, Zoom Metting, dan Whattsap group.

Kendala yang dihadapi guru dalam mengajar bahasa Jepang secara daring yaitu sinyal yang tidak stabil untuk melakukan pembelajaran secara daring karena tidak disemua daerah sinyalnya bisa bagus, kuota internet yang terbatas, siswa tidak mempunyai ponsel, kegiatan pembelajaran daring kurang efektif dibandingkan dengan luring, dan tugas semakin banyak sehingga siswa mengeluh dengan hal tersebut. 
Adapun saran bagi penelitian berikutnya yaitu hendaknya dapat menambah bahasan materi yang lain selain bahasa Jepang yang menarik bagi siswa.

\section{DAFTAR PUSTAKA}

Arikunto, Suharsimi. 2010. Prosedur Penelitian Suatu Pendekatan Praktek. Jakarta: PT Rineka Cipta.

Asano, Yuriko. 1981. Goi. Tokyo: The Japan Foundation.

Dimyati \& Mudjiono, 2013, Belajar Dan Pembelajaran, Jakarta: Rineka Cipta.

Hardjono, Sartinah. 1988. Prinsip-prinsip Pengajaran Bahasa dan Sastra.Jakarta:Dirjen Dikti PPLLPK Depdikbud.

Kuntarto, E. 2017. Keefektifan Model Pembelajaran Daring Dalam Perkuliahan Bahasa Indonesia di Perguruan Tinggi. Journal Indonesian Language Aducation and Literature. Vol. 3, No. 1, Desember 2017.

Moleong, Lexy. 2002. Metodologi Penelitian Kualitatif. Bandung: PT. Remaja Rosdakarya.

Nadia, 2020, Sistem Pembelajaran Daring Menggunakan Media Online Pada Era Covid-19, Jurnal Studi Pendidikan IPS, FKIP Universitas Lambung Mangkurat.

Nasution, 2008, Berbagai Pendekatan dalam Proses Belajar \& Mengajar, Cetakan keduabelas. Jakarta : Bumi Aksara

Nurdyansyah, dan E.F. Fahyuni.2016. Inovasi Model Pembelajaran Sesuai Kurikulum 2013. Sidoarjo: Nizamia Learning Center.

Phopam, W., J., 1994, Classroom Assessment: What Teacher Need To Know. Allin And Bacon, Boston.

Sudjianto, dan A. Dahidi. 2012. Pengantar Linguistik Bahasa Jepan. Jakarta: Kesaint Blanc.

Sugiyono. 2007. Metodologi Penelitian Pendidikan. Bandung: Alfabeta.

Suyono dan Harianto, 2012, Belajar dan Pembelajaran, Bandung: PT Remaja. Rosdakarya

The Japan Foundation.2009. Buku Pelajaran Bahasa Jepang "Sakura" Skenario Pembelajaran. Jakarta: Dit. Pembinaan SMA, Ditjen. Manajemen Dikdasmen, Kementerian Pendidikan Nasional RI. 